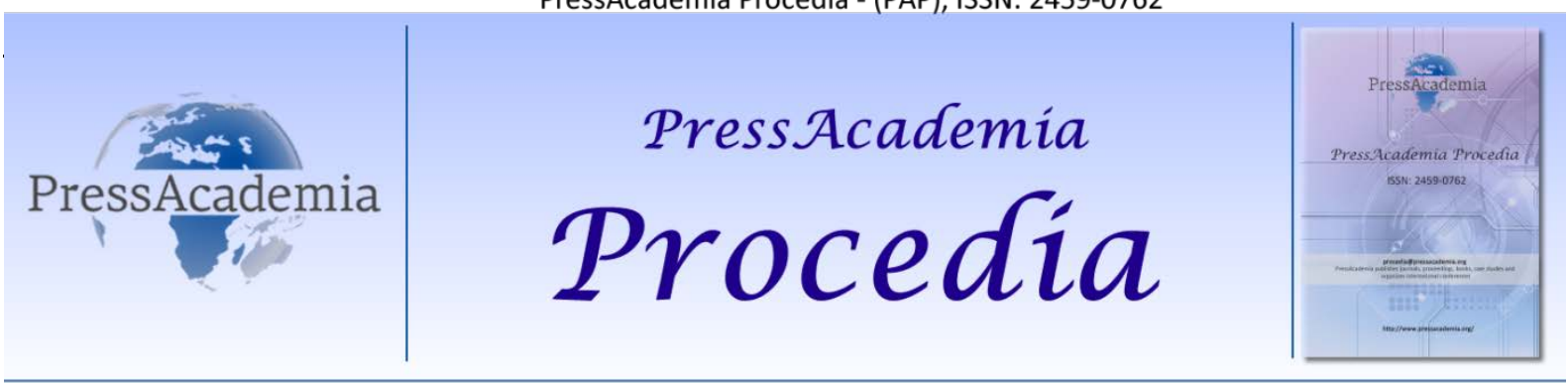

Global Business Research Congress (GBRC), May 26-27, 2016, Istanbul, Turkey.

\title{
AIRPORT SLOT COORDINATION SYSTEM: AN IMPLEMENTATION AT ATATURK AIRPORT
}

\section{DOI: 10.17261/Pressacademia.2016118632}

\author{
Savas S. Ates ${ }^{1}$, Mevlut Uzulmez ${ }^{2}$
}

${ }^{1}$ Anadolu University. ssates@anadolu.edu.tr

${ }^{2}$ Anadolu University. mr_mevlut@hotmail.com

\begin{abstract}
To realize the airline service process, an airline has to have numbers of services in different level such as ground handling, passenger/cargo terminal service, airport navigation service, customs service, security service etc. Because of the concept of the service, producing and consuming take place at the same time. Therefore, airport capacity should be planned, monitored and managed in advance by assigning time, park position and boarding/unloading process. Airport capacity is detected with the assessment of construction of facilities and other factors affecting the capacity. This acquired capacity is allocated to the demanders according to specific conditions and privileges. In the first stage of this paper, the theoretical research of airport slot coordination system has been examined. In the second part, with the data acquired by study in practice airport coordination, slot, slot types, slot allocation and slot allocation types has been stated with tables. In the final part of the study, the categorization of slot allocation has been discussed and evaluated by employees working at both airport and airline business by means of semi-structured interview. With analyzing the obtained results, the slot coordination system used in Atatürk Airport has been identified and on the purpose of improvement of system some recommendations have been made.
\end{abstract}

Keywords: Airport, airport slots, factors affecting airport capacity, airport slot coordination system, slot allocation JEL Codes: L93, R41, L98

\section{INTRODUCTION}

In transportation people highly attach importance to speed and comfort. Regarding to technologic and social development, this importance has been growing day by day. This affects the demand increase to air transportation. Air transportation has been growing up not only around the world, but also in Turkey. Aircraft fleets of airlines have been also growing thanks to great raise in demand. One of the most important mission of airport management has become efficient and productive capacity use because of the growing airlines. The growth in airway traffic brings congestion with it. Airport congestion is one of the most challenging reason for delays. Delays cause decreased profit and disruption in schedule structure. Instead of construction of a new facility, it would be a better approach that management of current capacity for both environmental and economic reasons. Without making any concession, managing efficient capacity is one of the most important goal of airline business. For that reason, airports use slot coordination systems. Slot coordination system is planning the departure and arrival time under control of airport capacity. The main purpose of the system is using the airport capacity in the most efficient way and disregarding the priority of the airline which cannot use it as planned.

\section{LITERATURE RESEARCH}

Airport Capacity is the throughput rater i.e. the maximum number of operations that can take place in an hour. Delay is the difference in time between a constrained and an unconstrained aircraft operation. These 
definitions take into account that delays occur because of simultaneous demands on the facility. The acceptable level of delay will vary from airport to Airport (FAA, 2016). The throughput method for calculating airport capacity and average delay per aircraft is derived from computer models used by the Federal Aviation Administration (FAA) to analyze airport capacity and reduce aircraft delay. Calculations of hourly capacity are needed to determine average delay. Since airport and airport component hourly capacities vary throughout the day due to variations in runway use, aircraft mix, ATC rules, etc., a number of calculations may be needed (FAA, 2016).

Runway capacity of an airport is not the same all the time. Capacity may vary depending on physical and functional factors such as airport, airspace geometry, air traffic inspection rules, meteorological conditions and aircraft. (Wells \& Young, 2004)

The factors causing delay and reducing the capacity can be gathered together under 4 main title (Kıyıldı, 2005) :

- $\quad$ Airside terminal capacity

- Air area capacity

- Ground transportation capacity

- Passenger terminal capacity.

Airside facilities are runway, taxiway, apron and gates (Wells \& Young, 2004). Because of any action in any airside facility affects the other component of capacity, general airside capacity will be specified with the most restricted part (Horonjeff, McKelvey, Sproule, \& Young, 2010). Growing demand on air transportation has caused creation of new low cost carriers and enlarging the fleet, so that air way capacity had to face with congestion. Inadequate capacity of airspace is one of the main reason of congestion in airways (Kıyıldı, 2005). Airports are one of the most crowded places which have both passenger and cargo traffic. Airport connection ways face serious capacity problems. Type, size and function of terminal building affect annual passenger capacity (Wells \& Young, 2004).

To allocate the airport capacity, a coordination action whose environment, methods and principles are set is needed. Coordinator can be an individual as well as company. There is a Center Committee to inspect and improve the coordination center and functions (Cengiz, 2012). Airport coordination has to keep the capacity under control regarded to WSG(Worldwide Slot Guidelines). Coordination aim to provide operation which is adequate the limited capacity to both airlines and other aircraft operators. It also tries to maximize the efficient use of airport infrastructure. Coordination should be regarded as a temporary solution till a new permanent method is improved to avoid the congestion (IATA, 2015).

Slot is given allocation of time period from the capacity (such as runway, park position, terminal area) to airlines. In another saying, to optimize the use of busy airport, sharing traffic to each day of week and each hour of a day as fair as they can (Özkoçak, 2015). Goal of European frame is to provide the maximum and most efficient capacity use in very competitive airports (EEC, 2015). Airport slot is a limited or complete facility permission to take-off or land given by coordinator in level 3 airports to aircraft operators (IATA, 2015). Aircraft operator should not be operating out of given slot time. Slot time should match with both passenger ticket and calculated take-off time. Operators should act according to slot time precisely. The permission approved from ATC cannot exceed the period of airport slots. Airport slot is defined and calculated not take-off/landing time but on/off clock time (Airport Coordination Limited, 2013). If the airport's slot demand exceeds the supply, this airport is considered as a "capacity-limited airport", in this point, slot allocation takes over the coordination. This congestion (time that demand exceeds supply) may be a specific time period of a day or specific day of a week or even seasons of a year (ICAO, 2013). Technically, slot allocation - especially in the congested airportsrefers to a permission that is taken from administration in advance to make use of infrastructural facilities of an airport. This term is legally based on Chicago Convention. Regulation of European Union number 793/2004 and different 95/93 regulation are directly related with airport slot allocation. Under the frame of regulation of EU, the latest regulation number 1459/2006 and slot allocation rules into temporary exception has been dispatched. In regulation "slot allocation" subject is specified under the slot application instruction in head of DHMi. After an airport slot has been allocation to aircraft operator, they can operate national and international flight rights based on regulations (Cengiz, 2012). 
Nowadays, one of the most challenging problem which air committees face is regulation the slot allocation to avoid the congestion at huge airports. For that reason, academically and technically lots of model has been suggested. Successful airport slot allocation system has to achieve two things at the same time: increasing capacity to vanish the effect of problem and provide the highest quality for all users of airport (Cohen \& Odini, 1985).

Slot allocation approaches under two titles:

- Administrative Approaches

o Historically-based (or "current-use-based") allocation

o Allocation on the basis of optimization

o Allocation by lottery

o Scheduling committees

- Auctions

\section{DATA AND METHODOLOGY}

Main objective of this study is to evaluate the importance of slot coordination for both airlines and airports. As a result of this study, it is hoped that this study may help a way as a solution for the situation which causes potential capacity problems. At the theory part, national and international manuals, previously written doctoral and master's thesis and number of essay related to topic have been examined. In addition to that, "IATAWorldwide Slot Guidelines" which is used for both airport and airlines as a resource to create their manual and "SHT-Slot Tahsis Talimatı" which is published by SHGM have been examined. This study has been implemented at İstanbul Atatürk Airport and one airline because of the time and cost limits. The names of airline and people have been coded because of the fact that they do not want to share. Implementation has been made by semistructured interview. In the light of answers, we have got, new questions have been added and some of them have been changed.

\section{FINDINGS AND DISCUSSIONS}

\section{Demographic structure of attendants}

Employee who is working for airport slot coordination has been coded as $\mathrm{H} 1 . \mathrm{H} 1$ is 55 years old and working for this job for 31 years.

Employee who is working for Airline Company has been coded as $\mathrm{H} 2 . \mathrm{H} 2$ is 45 years old and working in airline sector for 23 years.

\section{Identification of daily, weekly and seasonal capacity in Atatürk Airport}

According to $\mathrm{H} 1$, there is no annual and monthly capacity. Slot capacities are seasonal and each one has been calculated individually. Moreover, VFR flights are out of slot coordination system. After the capacity has been declared, slot allocation will take place. According to $\mathrm{H} 1$, slot capacity is measured by three criteria.

- Number of slot based take-off and landing,

- Hourly terminal capacity, (generally measured by B737 [150 passengers average])

- Park place criteria

Results related to function of slot coordination are:

- Finding bottleneck after the combination of three criteria above.

- This value identifies the hourly capacity.

- After capacity is pointed out every unit will be informed.

- Capacity will be allocated from scheduled airlines to charter.

If there is any gap in capacity, rest of slot will be allocated to unscheduled and charter airlines. 
Assessment of slot allocation approaches from the point of airport authority are:

- Equity and authority attitude in slot allocation (H1): IATA rules are in use in slot allocation. Airport slot is under control of government as soon as it is taken. After they arranged bilateral agreements, civil aviation authority allocates available slots to airlines in particular to flag carriers. Especially flag carriers have privilege because of grandfather rights they had.

- $\quad$ Loser and winner of current system (H1): Winning or losing are rather related to the rules. In valid system, the winner is the one who once got the slot and uses it every season at the higher limit of specified which is $80 \%$. If an airline cannot use its slot more than $20 \%$, the slot directly goes to the slotpool and airline loses its privilege for the next season.

- $\quad$ Auction approach in slot allocation (H1): In current system Atatürk Airport does not have this approach. There are some difficulties to let this approach take place in this airport. Auction approach is based on completely economic thought. Especially if there is few or only one airport available, this may lead monopolism.

Commercial interests should be at second place otherwise there will be deviation from real purpose. Just because airports are highly strategic points and have potentially huge amount of income, giving more share than necessary to other countries or airlines may not be wise choice at all.

\section{Factors affecting slot coordination system}

Sorting in slot coordination is set as "slot - permi - plan ". After getting a slot from airport, permi needs to be taken by bilateral agreements. After these two are done, flight plan should be sent to necessary units. This flight plan goes directly to the EUROCONTROL. EUROCONTROL takes all of these plans and put in an order according to СТОТ (calculated take off time). If there is no problem with matching СТОT and airport slots, plan will be set as scheduled.

Slot coordination and monitoring according to airport operator are:

- Factors affecting coordination office (H1): Aerodrome NOTAM's, meteorological conditions, information from ATC, SNOWTAM, accident/incident, VIP flights.

- Slot monitoring (H1): After airport has got flight data process, information will be sent to the slot office. FIC(Flight information center) matches the capacity and flight plans. In case of any discrepancy, offer new plan or change. If there is no problem, all information will be shared with ATC, en-route control etc.

- Slot monitoring and development of coordination system (H1): To improve monitoring and coordination, international effect which is nature of sector should be decreased into minimum levels. Because of high level of crowd, possible dangers which may affect safety should be calculated and decreased. To improve slot coordination in order to meet the need of demanders, safety should be taken into consideration first.

To monitor slot coordination, lots of information technology systems are integrated. Two important subjects in slot coordination are:

- Safety

- $\quad$ Flow management

A safe coordination system which meets airline needs should grow continually. It is quite fair to reach the conclusion that economic interest is the second priority in Atatürk Airport.

\section{Slot coordination activities with regard to airlines}

According to $\mathrm{H} 2$, slot coordination system is one of the most important thing in survival of an airline. Each airline wants to create a pick hour according to their schedule. If it is the one which uses hub-and-spoke 
system, they want to adapt different flight wave to hub and spoke their passengers. If an airline cannot reach this achievement, it can lose their passengers.

Slot demand from the point of airline companies are:

- Getting a slot from the point of airline $(\mathrm{H} 2)$ : Airlines have to find necessary slot related to their schedule in order to follow their politics and grow their company. Capacity of airport may not allow airline to get accurate slot every time as they planned.

- Alternative slots (H2): If airline has undesirable slot for desirable destination, demand should be analyzed again and if demand is still high the slot should be utilized. If the demand is low profitability of slot should be checked and related policies should be carried out. These policies are accepting the lack of frequency increase or giving up profit for a while till they get enough demand again.

- Effect of Marketing structure of airline to alternative slot (H2): If airline is monopoly in chosen destination, in other words, there is no other airline flying to that point, demand will not be affected.

Getting accurate slot for airlines is quite challenging because of the occupancy rate. If an airline cannot find desirable slot for their destinations, those questions should be asked:

- Slot at different hours will reach my targeted occupancy rate?

- Are we monopoly in destination that we ask slot for?

\section{Effect of slot coordination to airlines' preferences}

Slot coordination affects airlines especially for choosing route and its sustainability. Because of limited slot, we learnt that it should be used as sufficient as they can with choosing adequate aircraft and capacity research. While cancellation and delay in slot, airlines should draw attention to those they do not want to lose.

Importance of Slots for airlines and decision of slot cancellation and delays are:

- Most desired slots (H2): Firstly, the most profitable route should be decided. Especially when a slot is economically profitable, there are lots of competitors trying to get it. That is why, after controlling the slot with your scheduled, airlines demand the slot to maximize their profits.

- Slots which is not used as demanded as it is (H2): If an airline uses the taken slot more than $80 \%$, it gets privilege to take it for the next season. If they cannot meet this limit, airlines both get punishment for delay in actual operation and lose privilege to get the slot.

- Effect of slot on delay and cancel (H2): Some slots -just because they have precious strategic opportunity- are more important than others. Airlines try not to cancel and lose these slots. In a situation such as meteorological, slot congestion etc. airlines cannot extend their web. However, airline can decide which slot should be on-time or delayed.

- $\quad$ Slot preference in cargo flights (H2): Cargo flights is used to transport different kind of goods. They are dispatched in of-pick hours. Despite the fact that cargo flights can wait, some cargo flights are connected as well as passenger flights. For that reason, they can also be operated in rush hours.

- Effect of scheduled and charter flights on slot demand ( $\mathrm{H} 2)$ : There is a close relationship between slot demands and customer profile. If passenger wants to be the place he wanted to fly on time, airline should manage this need. This situation directly affects the slot request. After calculation the cost and requesting an off-pick slot is for charter operators. Just as their way service, charter flight costumers also vary depending on cost.

\section{CONCLUSION AND RECOMMENDATIONS}

Slot coordination is generally one of the most important point for airlines. It is quite fair to look the slot coordination on behalf of both airlines and airport.

In terms of airport, an attitude which is based upon equality principle needs should be in force. In a current system in Atatürk Airport there is no auction approach. Getting this approach into a current system may cause 
some problems. Because this approach requires a complete economic way of thinking. Especially in such places like airport, in the light of there is few or sometimes only airport around the territory, this approach may cause monopolistic system.

According to aircraft operator, getting adequate slot in Atatürk Airport, alternative slots and effect of marketing on slots are determined as important factors. It is quite obvious that effect of slot coordination on airlines -especially in congested routes- affects their preferences. Slots which are not used as it is wished affect operational decisions in airlines. If the airline is permitted to cancel or delay the flight, they can decide depending on slots. Apart from this, in some non-scheduled and charter airlines, slot allocation is run in a different way.

There may be some bottleneck at Atatürk Airport occasionally because of negative weather etc. In this kind of situations, capacity of airport decreases so that airlines have to cancel some of their slots. These cancellation decisions should be discussed not only in each airline but also between them to find controlled and economic way out and avoid bottleneck without having more displeasing situations.

\section{REFERENCES}

Airport Coordination Limited. (2013). Guidance on Slot Allocation and Slot Monitoring. In A. C. Limited, Airport Coordination Limited (pp. 14). London: Airport Coordination Limited.

Cengiz, A. (2012). Avrupa Birliğive Türkiye’de Slot (Sıra/Zaman) Tahsisiuygulaması ve Hukuki Değerlendirme. İzmir: Dokuz Eylül Üniversitesi.

Cohen, D., \& Odini, A. (1985). Flight Transportation Laboratory Report R85-3 /A Survey Of Approaches To The Slot Allocation Problem. Cambridge: Flight Transportation Laboratory.

Czerny, A. I., Forsyth, P., Gillen, D., \& Niemier, H.-M. (2008). Airport Slots. Burlingston: Asgate Publishing Company.

EEC. (2015, 12 06). Allocation of time slots. Retrieved from eur-lex: http://eur-lex.europa.eu/legal-content/EN/TXT/?uri=URISERV:I24085

FAA. (2016). Airport Capacity and Delay. Retrieved from http://www.faa.gov/documentLibrary/media/Advisory_Circular/150_5060_5.pdf

Horonjeff, R., McKelvey, F. X., Sproule, W. J., \& Young, S. B. (2010). Planning and Design of Airports. New york: McGraw-Hill Companies, Inc.

IATA. (2015). Worldwide Slot Guidelines. Montreal - Geneva: IATA.

ICAO. (2013). Worldwide Air Transport Conference (Atconf) Sixth Meeting. Montréal: International Civil Aviation Organization Secretariat.

Kıyıldı, R. K. (2005). Havaalanı Kapasite Analizine Yeni Bir Yaklaşım. Isparta.

Özkoçak, i. (2015, 12 06). 2006/1459 Sayılı Uçuş Tarifeleri ve Slot Tahsisine Yönelik Yapılan Anlaşma, Karar ve Uyumlu Eylemlere İlişkin Grup Muafiyeti Tebliği Üzerine Açıklamalar. Retrieved from http://www.escrc.com/: http://www.escrc.com/article/4075/2006-1459-sayili-ucustarifeleri-ve-slot-tahsisine-yonelik-yapilan-anlasma-karar-ve-uyumlu-eylemlere-iliskin-grup-muafiyeti-tebligi-uzerine-aciklamalar

Smith, A. D. (2004). LAGUARDIA SLOT ALLOCATION A Clock-Proxy Auction Approach . University of Maryland: Maryland .

Wells, A. T., \& Young, E. B. (2004). Airport Planning and Management ( 5.th edition ed.). New York: McGraw-Hill Companies. 